DOI: $10.14451 / 2.146 .13$

\title{
ПРОБЛЕМА «ГОСУДАРСТВЕННОСТИ» В ТЕОРИЯХ ПОЛИТОГЕНЕЗА
}

\author{
(c) 2020 Красников Иван Сергеевич \\ E-mail: krasnikov.iwan@yandex.ru
}

В статье выявлена сложившаяся недостаточность инструментария в области исследования политико-правовых феноменов. Автор формулирует собственную модель организации разрозненных представлений о становлении «государственности» как социального феномена. В основе предлагаемой концепции заложена идея дихотомического противопоставления цивилизационного возраста глобальных политий (образы государственности с протяжённой и краткой родословной). Центральная идея подобной концептуализации основана на обобщении многообразия трактовок «государственности» по их отношению к феномену политогенеза. В статье показана субстанциональная отличность политических общностей нововременных институтов.

Ключевые слова: полития, вождества, государственность с краткой и протяжённой родословной, нововременной, политогенез.

Термин «полития» пока не укоренился среди исследовательского сообщества. Одно из следствий этого - создание терминологических оксюморонов из противоположных по смыслу слов. (Критика использования плеоназмов в юридической науке представлена в работе Репина [18, с. 17, 19, 37-40].) Например, таких, как: «древнерусское государство», «античное государство», «американское...»; Преодоление такой тенденции позволит отказаться от компромиссных прилагательных, которые добавлялись авторами с целью показать разницу между сегодняшним государством и «ранним». Всё видовое разнообразие политических общностей (социальных институтов, которые институциализировали определённый тип власти - дистрибутивную (коллективную) или индивидуальную - корректно располагать внутри понятия «полития». Вместе с тем, античный полис (polis), локальный подконтрольный доминион (regnum), равным образом модерновую форму организации власти (state) и др. большинство исследователей продолжают втискивать в понятие «государства».

Термин же «полития» позволит отказаться от неубедительных концепций государственности с бесконечным прошлым, восходящим ещё в донеолитическую эпоху. Теоретическое следствие у нелинейно-поступательного подхода к эволюции политии выражается в дифференциации её форм. Это, в свою очередь, влечёт отказ от априорной приемственности признаков между разными видами политий, даже внутри одной формы (например, тождества между nation state и constitution state, и уж тем более polizeistaat).

Однако каким образом можно сгруппировать исследовательские подходы, которые настаивают на долгом прошлом «государства», и те, которые считают, что та государственность, в котором пребывает человечество в настоящем, оформилась не раньше XV-XVI вв.? Согласно исследовательскому подходу, применяемому в данной работе, первая группа представлений является ошибочной, но научный метод предполагает умение классифицировать и ложные проекции.

Авторской концепцией является попытка развить теорию «родословной» государственности. Точнее не развить, а сформулировать, поскольку как таковой теории нет, но есть сам термин - «родословная», применительно западным формам публичной власти, который обосновался в науке, благодаря работам Скиннера [27] и Андерсона [1]. (Характерно, что принадлежность к разным исследовательским традициям сказалась на названиях работ, посвященных одному периоду.) Данный концепт основан на аналитической традиции изучения социокультурных оснований появления какого-либо феномена, в том числе и политического. Например, Скиннер в своих работах обстоятельно изучает идейные основания нововременного периода в жизни Европы, чтобы показать «закономерности» оформления тех институтов, которые выделились в данный период времени [19].

Можно сказать, что в социальной науке ещё не сложился конструкт, который бы назывался концепция государственности с длинной родос- 
ловной (statehood with a long pedigree). Это конструкт, обобщающий теоретические представления разных теорий о преемственности развития государственности. Приверженцы такой модели те исследователи, которые полагают, что государственность - имманентно заложенная форма организации политических институтов социума.

Тем самым, история государственности началась ещё при формировании первых вождеств (обычно скрыто под термином «ранее государство» [Еллум, 22, с. 595]; приверженцы классовой теории называют этот период обычно «догосударственным»). Государственность в такой интерпретационной модели выступает в качестве образа крупномасштабного «вождества», которому удалось подчинить другие народы и земли. Некоторые авторы даже усматривает в этом периоде зарождение «империализма» [Лаат, 11, с. 404]. Неудивительно, что завершённость такой концепции была обретена в рамках марксистской линейности - теорий формаций.

Последовательность развития концепции государственности с длинной родословной является зеркальное её преломление, обобщающее противоположенные исследовательские модели,- это государственность с краткой историей (родословной).

Суть таких представлений сводится к следующим позициям:

1. разделять политогинез на эволюционные развилки, предполагающие институциональные аналоги государственности, отсутствие предзаданности «государства» как феномена социальной эволюции [17];

2. сводит возникновение государственности как социального феномена к появлению нововременного (VII-VIII вв.) политогенеза, характеризующегося оформлением нового типа коллективных отношений - публичной власти (В терминологии Бурдье - в данный период происходит «рождение публичной политики», «публичного поля» [3, с. 628]. Тогда же происходит «генезис понятия гражданина как противоположности понятия подданного» [3, с. 629]);

3. рассматривать аналоги государственности не в функциональном измерении (что свойственно, например, для представителей австрийской экономической школы), а полиморфном качестве [13, с. 8-9 и др.], не сводимым к выполнению государственностью определённых функций. Это признак не является определяю- щим для концепции государства с краткой историей: он обобщает методологические установки лишь некоторых исследователей, которые прямо заявляют о неисчерпаемости или вовсе «побочном» эффекте функций государственности. Ряд исследователь, описывая функциональное измерение государственности, не обобщают их до субстанционального качества.

Применяя в действии второй подход (концепцию государственности с краткой родословной), корректным названием для ранних политических образований будет домодерновые формы политий, для современных - (после)модерновые. Таким образом, «модерн» выступает тем таксоном (критерием), который разделяет не только мир идей на эпохи «до» И «после», но изменяет видовые конфигурации политических общностей, порождая новые формы организации властных отношений. В связи с этим возникает потребность изучить феномен «модерна» в политико-правовой теоретической интерпретации.

Самый примитивный, но при этом самый распространённый способ интерпретации «модерна» сводится к приравниванию (тожеству) с понятием «современность» [14, с. 11]. При этом сам термин «современность» остаётся таким же смысловым неопределённым, как и сам термин «модерн». Интуитивно-понятный механизм освоения понятия происходит при уподоблении концепта «современности» тому социальному пространству, в котором проживает человек «сейчас». Очевидным следствием этого становится наращивание «современностей», что сказывается и на терминологии «постмодерн», «пост-постмодерн» и т.д. (В связи с этим модель «маятника Чижевского» приобретает новое эвристическое значение в качестве прогноза появления новой терминологии [6, с. 10].)

Однако специальная литература, посвящённая анализу этого феномена, опровергает подход, создающий эквивалентность между пребыванием в настоящем («современностью») и концепцией «модерн». Такая позиция обусловлена тем, что эпоха модерна создаёт особое социально-культурно пространство, которое изменяет, том числе политико-правовую действительность.

Именно в этот период рождается теория естественных прав, которая успеет реинкарнироваться в XX в, после её забвения в XIX [25, с. 86]. Однако каким образом идеи естественных прав, 
так и концепция «общественного договора» смогла институциолизироваться? Ведь появление идеи, ещё не означает изменение социальной реальности под её влиянием. Можно фокус исследовательского внимание скорректировать в такую плоскость: каким образом происходил процесс нормативизации правовых ценностей в социально-политической культуре Нового времени?

Объяснение этого феномена возможно, если выйти из дисциплинарных коридоров теории права, обратившись к обобщениям, сформулированных в других описательных науках.

Наиболее убедительная теория, которая раскрывается феномен нововременного политогенеза - это концепция «развития индивидуальности», «пробуждения личности» [4, с. 88-91, 586]. Такая постановка проблематики имеет важное следствия для теоретизации о политических общностях: государственность - это продукт культуры (производное политико-правовой культуры). Иначе говоря, «...государство, определяемое культурой» [Гусейнов, 8, с. 11]. Это подтверждает подход, выбранный ещё Муромцевым, о стремлении познания правовых явлений через правовые культуры, а не национальные порядки, которые в свою очередь могут быть лишь частным проявлением, действующих в данной системе принципов [15, с. 18, 41 и др.]. Такой подход методологически схож с мир-системным анализом, которых оформился значительно позже (известный представитель мир-системного анализа Валлерстайн [5]).

Характерно, что Новое время изменило правовой «космос». В этот период происходит становление прав человека не только как социального феномена (так называемые «права первого поколения»), но, что не менее важно, появляется их терминологическое отображение. Это способствует экспансии «прав» в другие социальные порядки, по крайне мере, освоения другими культурами на уровне смыслов (язык (нео) римской юриспруденции был выбран в качестве такого универсального кода), а не действительного изменения правовых порядков (отказ от механических представлений о возможности правовых рецепций происходит позднее [28]).

«Человекоцентричность» этого периода проявлялась в опредмечивании социального порядка человеческим измерением [16, с. 40]. Эта мысль хорошо иллюстрируется на изучении феномена «естественного права»: как эта концепция в этом период перестала обосновываться теорией божественного естества, уступив место естеству человеческому [25, с. 87]. Отрицанием можно считать и формирование противоположных мироощущению Модерна исследовательских традиций. Примером такого подхода, который в том числе и сказался на последующих правовых исследованиях, является теория циклов культурного развития Вико [2, с. 205]. С определёнными трансформациями, но аналогичный подход отразился в работах последующих правоведов. Так, идея права каждой нации на своё «государство» стало идейным фундаментом принципов, которые применялись представителями «исторической правовой школы» [7, с. 19-20 и др.]. Культурное и правовое разнообразие было положено в основу социологически-правовых исследований Сорокина [21, 571-614]. В текущей современности окончательное оформление идеи множественности нормативных порядков была обретена в рамках теории правового плюрализма [23, с. 153155]. Таким образом, можно отметить, сразу, что Постмодерн вышел из Модерна, как только появился запрос на контрмодерные идеи, которые имманентно присутствовали в нём всегда (причины такого «социального запроса» не входят в предмет теоретико-правового исследования).

Примечательно, но анатомия процессов, происходящих в Новое временя, представляет из себя отдельный сложный вопрос. Осознание конституирующего значения происходящих в нём изменений - их «авангардная» революционность по отношению к прежним - была осознана не сразу. Даже понятийный язык отставал от скорости изменений. Например, понятие «Возрождение» (этот символ и элемент Модерна) появилось в социальной обиходе с запозданием. Как указывает Февр в статье, вышедшей в 1950 году [24, р. 177], столетие назад термина «Ренессанс» ещё не было [24, с. 377]. При этом отмечает случаи спорадического употребления [24, с. 378].

Для европейского сознания стало необходимым создать новое фундаментальное обоснование строения социального универсума, в том числе большой её части - мира политических и правовых концепций. Переоформление действительности проходит под идей «контрактной» государственности. Левиафан как символ «государственности» (в греческой традиции - Минотавр [9, с. 25-40] оказывается в границах, очерченных не его природой, а человеческой. А последняя предполагает выполнение 
функций, ради которых она и учреждалась. Ожидание выполнения определённых «задач» зависело от идейного компаса того автора, который тереотезировал на этот счёт: от приверженцев «ночного сторожа» до эгалитаристских концепций $[10$, с. 63].

Таким образом, Модерн как культурносоциальное, и прежде всего как политикоправовое явление, началось на излёте позднего Средневековья. Это определение не хронологическое, а содержательное. Если для высоких Средних веков, действительно, применимо определение, которое дал Канторович («власть, тяготеющая к праву» [12, 163-255]), то право это всё ещё иномирное, не обретаемое и не исчерпаемое рамками позднейшей юридической техники (в широком смысле - прежде всего интерпретаций) явление. Но Новое время, особенно в одном из магистральных для себя направлений - гуманистики, преодолевается в себе, точнее, через себя: посредством нового языка и человекоцентричного мироощущения пиететом по отношению к римскому наследию. Цивилистическая культура («карикатурное» изображение итога этого же действия - шествие гражданских кодексов по Европе) - это не последствия рецепции римского частного права, а последствия его рождения в этой период. [19, с. 347]. Немецкоязычные специалисты по истории понятий, также подтверждают мысль о преодолении «Античности», её пересборки, а не о реконструкции (если этот термин вовсе применим к глобальным социальным проектам [20, с. 249]. Таким образом, можно говорить о том, что Модерн - это преодолении наследия «старого» Рима, создание новых правовых идеалов, пусть и символике древних феноменов - манифистирующей или подразумеваемой преемственности по отношению к наследию Античности.

\section{Библиографический список}

1. Андерсон П. Родословная абсолютистского государства / пер. с англ. Ивана Куриллы.- М.: Территория будущего, 2010. - 510, [1] c. - (Университетская библиотека Александра Погорельского).

2. Берлин И. Философия свободы. Европа / Предисловие А.Эткинда.- М.: Новое литературное обозрение, 2001.- $448 \mathrm{c}$.

3. Бурдье П. О государстве: курс лекций в Коллеж де Франс (1989-1992) / пер. с фр. Д. Кралечкина и И. Кушнарёвой.- М.: Издательский дом «Дело» РАНХиГС, 2016.- 720 с.

4. Буркхардт Я. Культура Возрождения в Италии.- М.: Юрист, 1996. - 592 с. - (Лики культуры).

5. Валлерстайн И. Мир-система Модерна. Том II. Меркантилизм и консолидация европейского мира-экономики, 1600-1750 гг. [2-е издание] / Пер. с англ., литер. редакт., комм. Н. Проценко.- М.: Ун-т Дмитрия Пожарского: Русский фонд содействия образованию и науке, 2016. -493 с.

6. Власов В.Г. Маятник Чижевского, или как история убивает гениев. Добавления к теории прогрессивного циклического развития Ф. И.Шмита // Архитектон: известия вузов. 2015. № 49. С. 10

7. Гирке О.ф. Естественное право и немецкое право // Савиньи Ф.К. фон. Система современного римского права. Т. I / Пер. с нем. Г. Жигулина; Под ред. О. Кутателадзе, В. Зубаря.- М.: Статут, 2011.510 с.

8. Государство как произведение искусства: 150-летие концепции / Отв. ред. А.А.Гусейнов.- М.: Летний сад, 2011. $-288 \mathrm{c}$.

9. Жувенель Б. де. Власть. Естественная история ее возрастания / пер. с фр. [А. В. Матешук, В.П. Гайдамака].Москва: ИРИСЭН: Мысль, 2010.-544 - (Серия: «Политическая наука»).

10. Завадский C. «Государство благоденствия». Доктрина и практика. / пер. с польского Б. Т. Челяпова, А. А. Якушев под ред. Г.Х.Шахназарова.- М.: Прогресс, 1966.- 376 с.

11. История человечества: В 8 т. Т. 1: Доисторические времена и начала цивилизации / Под ред. 3.Я.Де Лаата [и др.]; [Отв. ред. Э. А. Манушин]. - М.: ЮНЕСКО: Издат. Дом Магистр-Пресс, 2003. - 681 с.

12. Канторович Э.Х. Два тела короля. Исследование по средневековой политической теологии. Изд. второе, исправленное / Пер. с англ. М. А. Бойцова, А. Ю. Серегиной. - М: Изд-во Института Гайдара, 2014. - 752 с.

13. Манн М.Автономная власть государства: истоки, механизмы и результаты // Неприкосновенный запас. 2018. № 2 (118). С. 3-33.

14. Мартьянов В.С. Политический проект Модерна: от мироэкономики к мирополитике: стратегия России в глобализирующемся мире / В. С. Мартьянов.- М.: РОССПЭН, 2010.- 357 [1] с.

15. Муромщев С. Определение и основное разделение права. - М.: Типография А. И. Мамонтова и Ко, 1879. - 240 c.

16. Пелипенко А. А. Контрэволюция.-М.: Издательство «Знание», 2016.-240 с. 
17. Раннее государство, его альтернативы и аналоги / Под ред. Л.Е.Гринина, Д. М.Бондаренко, Н. Н. Крадина, А. В. Коротаева.- Волгоград: Учитель, 2006. - 558 с.

18. Репин Е. Н. Межевая теория права. Начала терминомии. [2020]. С. 17, 19, 37-40 и др.

19. Скиннер К. Истоки современной политической мысли. В 2-х т. Т. 1: Эпоха Ренессанса / перевод с английского Андрея Олейникова.- М.: Дело, 2018.- 461 с.

20. Словарь основных исторических понятий: Избранные статьи в 2-х т. Т. 1 / Пер. с немецкого К. Левинсон; сост. Ю.Зарецкий, К.Левинсон, И.Ширле; научн. ред. перевода Ю. Арнаутова.-М.: Новое литературное обозрение, 2014.- 736 с.

21. Сорокин П. А. Социальная и культурная динамика / Пер. с англ., ввступ.ст. и коммент. В. В. Сапова.- М.: Академический проект, 2017.- 964 с. - (Теории общества).

22. Теория и методы в современной политической науке: первая попытка теоретического синтеза: [сборник статей норвежских политологов] / под ред. Стейна Угельвика Ларсена; [пер. с англ. Е.А.Жуковой].- М.: РОССПЭН, 2009 (Ульяновск: Ульяновский Дом печати). - 750, [1] с.

23. Уакс Р. Философия права. Краткое введение / пер. с англ. С. Моисеева. - М., 2020.- 176 с.

24. Февр Л. Бои за историю. - М.: Наука, 1991. - 630 с. - (Памятники исторической мысли)

25. Шацкий Е. История социологической мысли. Том 1 / Пер. с польск. Барзова Е., Васильев А., Вертячих Н., Мурадян Г., Уразбекова А., Федорова В., Чехова О.- М.: Новое литературное обозрение, 2018.- 720 с.(Серия: Интеллектуальная история).

26. Perini L. Lucien febvre et la renaissance de jules Michelet // Revue européenne des sciences sociales. 1994. T. 32. № 98. La rationalité reconstruite et les sciences du salmigondis historique. $177 \mathrm{p}$.

27. Skinner Q. A genealogy of the modern state // Proceedings of the British Academy. 2009. P. 325-370.

28. Watson A. Legal Transplants: An Approach to Comparative Law. Front Cover. University Press of Virginia, 1974. $106 \mathrm{p}$. 